\title{
Magnetohyperthermia for treatment of gliomas: experimental and clinical studies
}

\author{
Magnetohipertermia para o tratamento de gliomas: estudos experimentais e clínicos
}

\author{
André César da Silva ${ }^{1}$, Tiago Ribeiro Oliveira² ${ }^{2}$ Javier Bustamante Mamani³ ${ }^{3}$, Suzana Mária Fleury Malheiros ${ }^{4}$, Lorena \\ Favaro Pavon ${ }^{5}$, Tatiana Taís Sibov ${ }^{6}$, Edson Amaro Junior ${ }^{7}$, Lionel Fernel Gamarra ${ }^{8}$
}

\begin{abstract}
Gliomas comprise a group of heterogeneous primary tumors of the central nervous system that originate from glial cells. Malignant gliomas account for the majority of primary malignant CNS tumors and are associated with high morbidity and mortality. Glioblastoma is the most frequent malignant glioma, and despite recent advances in diagnosis and new treatment options, its prognosis remains dismal. New opportunities for the development of effective therapies for malignant gliomas are urgently needed. Magnetohyperthermia consists of heat generation in the region of the tumor through the application of magnetic nanoparticles subjected to an alternating magnetic field and has shown positive results in both preclinical and clinical assays. The aim of this review was to assess the relevance of hyperthermia induced by magnetic nanoparticles in treating gliomas and to describe possible variations of the technique and its implication in the effectiveness of treatment. An electronic search in the literature of articles published from January 1990 to November 2009 was performed, in databases ISI Web of Science and PubMed, and after screening according to the inclusion criteria, 11 articles were selected. Animal models showed that magnetohyperthermia was effective in promoting tumor cell death and reducing tumor mass or increasing survival of the animals. One clinical study demonstrated that magnetohyperthermia could be applied safely and with few adverse effects. Some studies suggested that mechanisms of cell death, such as apoptosis, necrosis, and antitumor immune response were triggered by magnetohyperthermia. Based on these data, it was concluded that the technique proved to be effective in most experiments, and improvement of the nanocomposites, as well as of the alternating magnetic field equipment, can contribute
\end{abstract}

towards establishing magnetohyperthermia as a promising tool to treat malignant gliomas.

Keywords: Glioma; Central nervous system neoplasms; Hyperthermia, induced; Nanoparticles; Magnetics; Models, animal

\section{RESUMO}

Gliomas compõem um grupo de tumores primários heterogêneos do sistema nervoso central (SNC) derivados de células gliais. Gliomas malignos representam a maioria dos tumores primários malignos do SNC e estão associados a índices altos de morbidade e mortalidade. Glioblastoma é o glioma mais frequente e maligno e, apesar dos avanços recentes no diagnóstico e das novas opções de tratamento, seu prognóstico permanece obscuro. Novas oportunidades para 0 desenvolvimento de terapias efetivas para gliomas malignos são urgentemente necessárias. A magnetohipertermia, a qual consiste na geração de calor na região do tumor por meio da aplicação de nanopartículas magnéticas submetidas a um campo magnético alternado, tem apresentado resultados positivos em testes pré-clínicos e clínicos. 0 objetivo desta revisão foi verificar a relevância da hipertermia induzida por nanopartículas magnéticas no tratamento de gliomas e notar as possíveis variações da técnica e sua implicação na efetividade do tratamento. Realizamos uma busca eletrônica na literatura científica de publicações de Janeiro de 1990 a Novembro de 2009, nos bancos de dados ISI Web of Science e PubMed e, após a aplicação do critério de inclusão, obtivemos um total de 11 artigos. Estudos baseados em modelos animais demonstraram que a magnetohipertermia foi efetiva

\footnotetext{
${ }^{1} \mathrm{PhD}$ in Sciences, Instituto Israelita de Ensino e Pesquisa Albert Einstein - IIEPAE, São Paulo (SP), Brasil.

${ }^{2}$ MsC in Sciences, Instituto Israelita de Ensino e Pesquisa Albert Einstein - IIEPAE; PhD student, Instituto de Física da Universidade de São Paulo - USP, São Paulo (SP), Brasil.

${ }^{3} \mathrm{PhD}$ in Sciences; Instituto Israelita de Ensino e Pesquisa Albert Einstein - IIEPAE, São Paulo (SP), Brasil.

${ }^{4} \mathrm{PhD}$; MD of Departament of Neurology and Neurosurgery, Universidade Federal de São Paulo - UNIFESP; MD of Departament of Oncology of Hospital Israelita Albert Einstein - HIAE, São Paulo (SP), Brasil.

${ }^{5} \mathrm{PhD}$ in Cellular and Molecular Biology do Instituto Israelita de Ensino e Pesquisa Albert Einstein - IIEPAE, São Paulo (SP), Brasil.

${ }^{6} \mathrm{PhD}$ in Cellular and Molecular Biology, Instituto Israelita de Ensino e Pesquisa Albert Einstein - IIEPAE, São Paulo (SP), Brasil.

${ }^{7}$ PhD; MD of Instituto Israelita de Ensino e Pesquisa Albert Einstein - IIEPAE; MD of Instituto de Radiologia da Faculdade de Medicina da Universidade de São Paulo - USP, São Paulo (SP), Brasil.

${ }^{8} \mathrm{PhD}$ in Sciences, Instituto Israelita de Ensino e Pesquisa Albert Einstein - IIEPAE; PhD in Sciences, Instituto de Radiologia da Faculdade de Medicina da Universidade de São Paulo - USP, São Paulo (SP), Brasil.

The authors declare there is no conflict of interest.
}

Corresponding author: Lionel Fernel Gamarra - Instituto Israelita de Ensino e Pesquisa Albert Einstein - Avenida Albert Einstein, 627/701 - Morumbi - CEP 05651 -901 - São Paulo (SP), Brasil - e-mail: Igamarra@einstein.br

Received: Feb 07, 2010 - Accepted: Jul 15, 2010 
em promover a morte celular tumoral e reduzir a massa do tumor ou aumentar a sobrevida dos animais. Um estudo clínico mostrou que a magnetohipertermia pode ser aplicada seguramente e com poucos efeitos adversos. Alguns estudos sugerem que mecanismos de morte celular, tais como apoptose, necrose e resposta imune antitumoral foram desencadeadas por magnetohipertermia. Com base nesses dados podemos concluir que a magnetohipertermia foi efetiva na maioria dos experimentos e que o aperfeiçoamento dos nanocompostos, assim como dos equipamentos de campo magnético alternado, podem contribuir para o estabelecimento da magnetohipertermia como uma ferramenta promissora no tratamento dos gliomas malignos.

Descritores: Glioma; Neoplasias do sistema nervoso central; Hipertermia induzida; Nanopartículas; Magnetismo; Modelos animais

\section{INTRODUCTION}

In the past decades, one of the great challenges of oncologists and neuroscientists has been understanding the biological mechanisms involved in the development of tumors of the central nervous system (CNS), and developing effective therapies to stabilize, reduce and possibly eliminate these tumors. Primary malignant tumors of the CNS account for $1.49 \%$ of all neoplasms and, although rare, they are potentially fatal ${ }^{(1)}$. The majority of these tumors originates from glial cells and therefore is generically named gliomas $^{(2)}$. They comprise a heterogeneous group of neoplams that may be further subdivided according to the glial cell of origin (i.e., astrocytes, oligodendrocytes, ependymal cells, and choroid plexus cells) $)^{(3)}$. Gliomas are part of a group of neuroepithelial tumors and correspond to $33 \%$ of primary and $79 \%$ of malignant tumors of the CNS. Astrocytomas represent $75 \%$ of all gliomas, and glioblastomas account for $51.7 \%$ of all cases ${ }^{(1)}$. Glioblastomas are the most frequent and most malignant type of astrocytoma; and, despite numerous advances in diagnosis and treatment of these tumors, the prognosis is still considerably poor ${ }^{(4,5)}$. Thus, the development of more effective alternatives and minimally invasive therapies that stop the development or even promote the destruction of the tumor is of utmost importance. With this in mind, magnetohyperthermia (MHT) induced by magnetic nanoparticles (MNP) injected into the tumor site and subsequently exposed to an alternating magnetic field (AMF) has been regarded as an effective therapeutic tool, due to its capacity to destroy tumor cells ${ }^{(6-7)}$.

\section{OBJECTIVE}

The aim of this review was to find scientific reports that used MHT to treat gliomas. For this purpose, preclinical trials (use of MHT in tumor models) and clinical trials that used the technique as isolated or adjuvant therapy were included. Although gliomas are exclusively
CNS tumors, studies with animals presenting tumors implanted outside the CNS were also included, as long as the neoplams originated from glioma cell lines (for example, T-9 rat glioma cells).

\section{METHODS}

The literature search included publications from January 1990 to November 2009 and was conducted in the electronic databases ISI Web of Science and PubMed. The following keywords were used in search: "[(Brain tumor) or (glioma) or (glioblastoma)] and [(magnetic fluid hyperthermia) or (magnetic hyperthermia) or (induction heating)]". In this review, two authors (J.B.M. and T.R.O.) individually checked the titles and abstracts of the articles retrieved during electronic search. Then, three authors (L.F.G., L.F.P. and T.T.S.) checked the quality of the methods, inclusion criteria and data to be collected. Thereafter, three other authors (S.M.F.M., A.C.S., and E.A.Jr.) extracted the data and organized the results in tables.

The studies used in this report had to meet the following inclusion criteria: (1) to be published in English; (2) to be an original study; (3) hyperthermia must have been used to induce death of glioma tumor cells in humans and in animal models in the study; (4) a study in which iron oxide nanoparticles were used as hyperthermia mediator under the influence of an AMF.

\section{RESULTS}

The electronic search identified 69 publications. After applying the inclusion criteria, 11 articles were included in this study; in that, nine were investigations in animal models $^{(8-16)}$ and two in humans ${ }^{(17,18)}$ (Table 1). Despite the fact that several centers worldwide evaluate MHT as an oncological therapy, only two research centers focused on the use of MHT for treating glioblatomas: the Department of Biotechnology of the School of Engineering of Nagoya University, in Japan, and the Department of Radiology of the Medical University Charité, in Germany.

The studies selected for this review aimed to assess the use of MHT to treat gliomas in animal models and in clinical trials. Some of these studies associated the use of hyperthermia to other therapeutics approaches, and suggested possible mechanisms triggered by hyperthermia that lead to death of tumor cells.

\section{DISCUSSION}

\section{Effectiveness of magnetohyperthermia}

Out of 11 reports selected for this review, 9 evaluated the use of MHT in animal models, such as rats and 
mice. The remaining two studies reported results from human clinical studies. Thus, for the purpose of clarity, the description of the results was divided into in vivo experiments in animal models, and ex vivo and in vivo studies in humans.

\section{In vivo experiments - animal model}

\section{a) Therapeutic protocol in animal models}

Table 1 presents a comparison of the glioma animal models, and shows that selected studies evaluated the effects of MHT in tumors ranging in size from 3 to $18 \mathrm{~mm}$, with a highest frequency of 10 and $18 \mathrm{~mm}$, corresponding to five out of nine studies. However, there is one report ${ }^{(16)}$ that did not inform the dimensions of the tumor. In most studies (six out of nine), the cell line used to develop tumors was T-9 cells implanted in Fischer F-344 rats $^{(8-13,16)}$. The minimum amount of cells injected varied from $1 \times 10^{5}$ to $3 \times 10^{7}$ cells. In only two studies cells were implanted in areas of the brain $^{(8,16)}$, whereas in the remaining investigations the cells were implanted in subcutaneous tissue. For the interval of tumor dimension assessed in this review, the amount of iron introduced in the tumor ranged from $3 \mu \mathrm{g}$ to $3 \mathrm{mg}$, according to the therapeutical protocols presented in table 2 (considering eight articles that provided such information). In regard to heating time, table 2 shows that authors used protocols that lasted up to 60 minutes. But, in most studies, the treatment lasted 30 minutes. In our sample, seven articles favored increased number of AMF by rising exposure time of each application, with a maximum of three applications being reported (Table 2). The therapeutic temperature ranged from 43 to $47^{\circ} \mathrm{C}$, with $44^{(11,13,16)}$ and $45^{\circ} \mathrm{C}^{(9-10,12)}$ being more frequent. The majority of studies (seven out of nine) used MHT as an isolated treatment, whereas the two remaining studies $^{(9,15)}$ verified whether MHT associated with gene therapy could promote a more significant reduction of tumors.

\section{b) Magnetohyperthermia efficacy in animal models}

The efficacy of MHT in glioma models was first reported by Yanase et al. ${ }^{(10)}$, who used F-344 Fisher rats that developed tumors after subcutaneous injections of T-9 tumor cell cultures, which had been previously incubated with MNP, named cationic magnetoliposomes (CML). After 20 minutes of AMF, temperature reached $43^{\circ} \mathrm{C}$, with a maximum of $45^{\circ} \mathrm{C}$. Nevertheless, rectal temperature remained between 35 and $36.5^{\circ} \mathrm{C}$. The use of three 60-minute AMF applications in 12-hour intervals completely inhibited the growth of tumor cells in rats followed-up for 90 days.

One year later, Yanase et al. ${ }^{(11)}$ reported similar results, but this time CML were injected in tumors that had developed earlier in Fisher rats. After 15 minutes of AMF, the maximum tumor temperature reached $44^{\circ} \mathrm{C}$ with little variation of rectal temperature $\left(35\right.$ and $\left.37^{\circ} \mathrm{C}\right)$. The group receiving 3 applications of 30 -minute magnetic irradiation in 24-hour intervals had tumor reduction by $87.5 \%$. Histological analysis revealed that in the control group, which did not receive AMF, CML were restricted to the site of injection. However, the groups receiving AMF presented a homogeneous distribution of CML that coincided with necrotic regions.

In that same year, Yanase et al. ${ }^{(12)}$ investigated the possible anti-tumor immune response induced by hyperthermia in the same rat tumor model (T-9) described above, but this time tumor development was induced on both sides of the animal. Heat induction proved to be effective and reached $43^{\circ} \mathrm{C}$ at the tumor site after 10 minutes of AMF application. The group received three 30-minute magnetic irradiation sessions with 24hour intervals, and presented complete regression of

Table 1 - Comparison of the glioma animal models used to assess magnetohyperthermia (MHT) therapy

\begin{tabular}{|c|c|c|c|c|c|c|c|c|}
\hline Authors & $\begin{array}{l}\text { Tumor cell } \\
\text { line }\end{array}$ & Animal & Gender & $\begin{array}{c}\text { Age } \\
\text { (weeks-old) }\end{array}$ & Site of injection & $\begin{array}{l}\text { Minimum } \\
\text { inoculation } \\
\text { (cells) }\end{array}$ & $\begin{array}{l}\text { Days to initiate MHT } \\
\text { after inoculation of } \\
\text { tumor cells }\end{array}$ & $\begin{array}{l}\text { Size of tumor } \\
(\mathrm{mm}) / \text { shape }\end{array}$ \\
\hline Yanase M et al..$^{(10)}$ & $\mathrm{T}-9$ & Fisher rat F-344 & Female & $7-8$ & $\begin{array}{l}\text { Subcutaneous } \\
\text { (left femoral region) }\end{array}$ & $1 \times 10^{6}$ & - & 3/ellipsoidal \\
\hline Yanase M et al..(11) & T-9 & Fisher rat F-344 & Female & $6-7$ & $\begin{array}{l}\text { Subcutaneous } \\
\text { (left femoral region) }\end{array}$ & $1 \times 10^{7}$ & 11 & 13-18/ellipsoidal \\
\hline Yanase M et al. ${ }^{(12)}$ & T-9 & Fisher rat F-344 & Female & $6-7$ & $\begin{array}{l}\text { Subcutaneous } \\
\text { (left and right femoral region) }\end{array}$ & $1 \times 10^{7}$ & 11 & 13-18/ellipsoidal \\
\hline Ito $A$ et al..$^{(15)}$ & U-251-SP & Athymic mice & Female & 4 & Right flank & $3 \times 10^{7}$ & - & $8(-)$ \\
\hline Le B et al. ${ }^{(14)}$ & U251-SP & KSN-nu/nu mice & Female & 4 & $\begin{array}{l}\text { Subcutaneous } \\
\text { (femoral region) }\end{array}$ & - & 21 & 10/ellipsoidal \\
\hline Ohno T et al. ${ }^{(16)}$ & T-9 & Fisher rat F-344 & Female & 4 & Right cerebral hemisphere & $5 \times 10^{6}$ & 8 & - \\
\hline
\end{tabular}




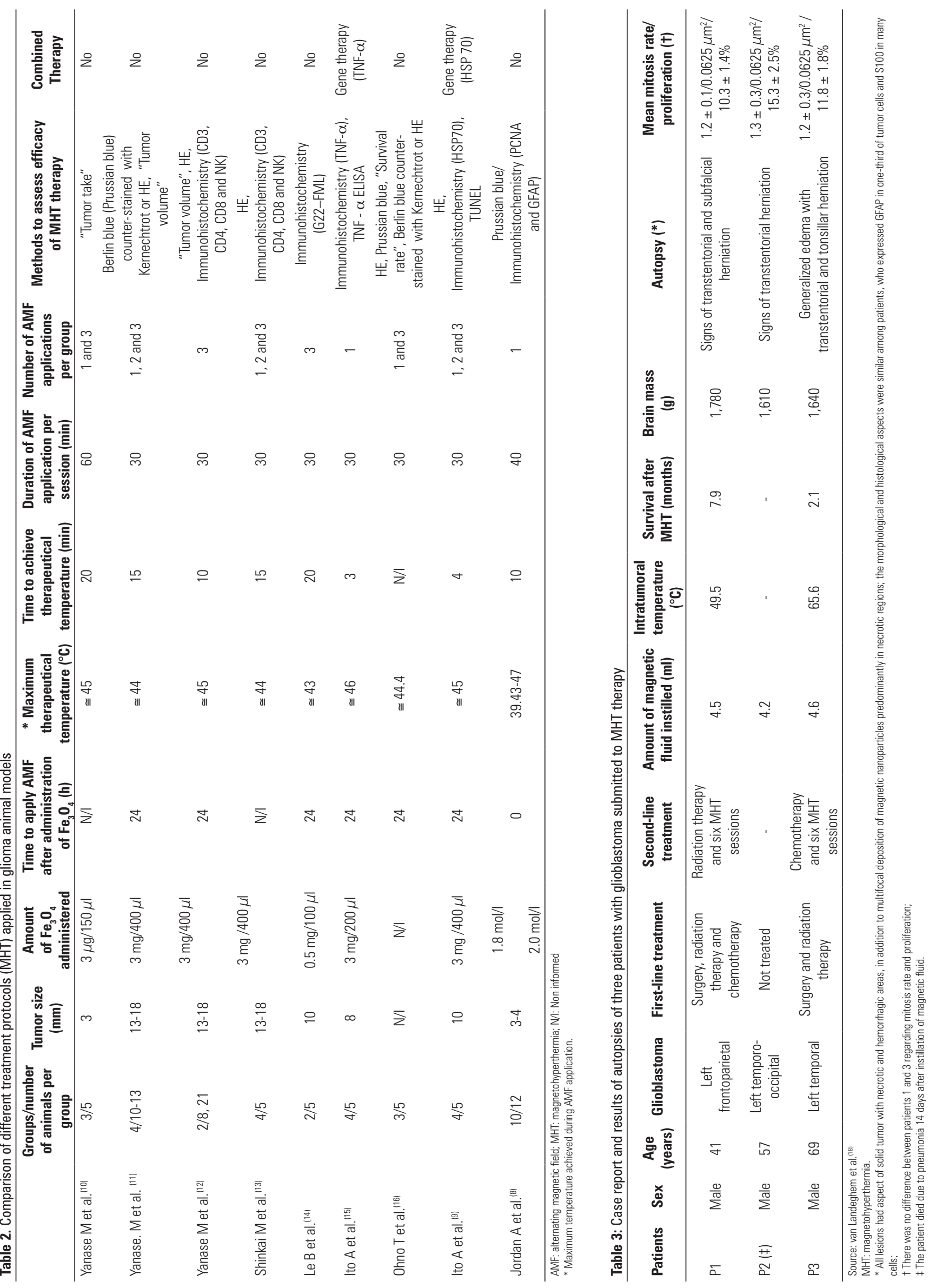


the tumor on the left side. Despite not receiving CML, the tumor on the right site also presented complete regression. Histological analysis revealed the presence of immunocytes (CD3, CD4, CD8 and natural killers NK cells) in the group exposed to hyperthermia at the tumor site on the left and right sides. Rats cured after magnetic irradiation were challenged again with T-9 cells and also with malignant fibrous histiocytoma cell lines and the authors observed that only these cells have developed, showing that the tissue presented a specific immune response for T-9 cells.

Shinkai et al. ${ }^{(13)}$ confirmed the same hyperthermiatriggered anti-tumor immune response observed by Yanase et al. ${ }^{(11)}$. After tumor growth (T-9 cells) in Fisher rats, these authors observed that after 15 minutes of AMF application, the maximum tumor temperature reached was $44^{\circ} \mathrm{C}$. The maximum AMF duration was 30 minutes, and animals treated with multiple magnetic irradiations during this interval presented complete tumor regression. After regression, tumor development was negative during a three-month follow-up period. Approximately $80-90 \%$ of injected CML accumulated in the tumor tissue. Therefore, the authors suggested that tumor regression and no tumor relapse were due to hyperthermia-induced immune response (activation of CD4, CD8 and NK-cells). ${ }^{(14)}$

In 2001, Ito et al. ${ }^{(15)}$ suggested that hyperthermia combined with gene therapy could be an effective option to treat tumors. Tumor development was induced through the implantation of human glioma cells (U251SP) into the flank of mice. The use of AMF in the tumor under presence of CML generated heat up to $46^{\circ} \mathrm{C}$ after 3 minutes. The simultaneous injection of pGadFNT, a tumor necrosis factor (TNF) promoter activated by hyperthermia and CML after AMF application, increased the expression of TNF- $\alpha$ gene. The combined use of pGadFNT and CML, and subsequent application of AMF, caused dramatic tumor shrinkage, which was more significant than that observed in groups where these compounds were used as single therapy.

Still in 2001, Le et al. ${ }^{(14)}$ demonstrated that the efficacy of CML in tumor destruction could be enhanced if these liposomes were conjugated to a fragment of tumor specific antibodies (Fab fragment). Thus, they developed tumors in mice using human glioma cells (U251-SP). The study showed that cell uptake of CML conjugated with Fab antibody was seven times higher than uptake of CML without a specific antibody. Furthermore, after AMF, tumor temperature rose fast up to $40^{\circ} \mathrm{C}$ within 5 minutes, and at $43^{\circ} \mathrm{C}$ after 30 minutes. In addition to that, tumor growth was inhibited for up to two weeks.

In 2002, Ohno et al. ${ }^{(16)}$ tested the efficacy of a new magnetite-based nanoparticle called stick type carboxymethyl cellulose (CMC) in generating heat. This
MNP was evaluated in tumors developed in the brain of Fisher rats after T-9 cell inoculation. The nanoparticle effectively heated the tumor tissue at $44.4^{\circ} \mathrm{C}$ after AMF application, and was vastly distributed after three applications. The study revealed that the nanoparticle did not invade the normal adjacent brain tissue. Total remission was observed in only one animal of the group treated with three MHT sessions. Furthermore, this was the group that presented longest survival time when compared to the other groups. Thus, data showed that this nanoparticle effectively induces hyperthermia.

Studies by Ito et al. ${ }^{(15)}$ continued to support the role of hyperthermia as an agent that induces antitumor immune factors. In this study, they evaluated whether hyperthermia could activate heat-shock proteins (HSP), which, in turn, would trigger an antitumor immune response. Tumors developed in Fisher rats after subcutaneous inoculation of T-9 cells. The application of AMF on the tumor in the presence of CML generated heat up to $42^{\circ} \mathrm{C}$ after 4 minutes, achieving a maximum of $45^{\circ} \mathrm{C}$. Heat increased the expression of HSP70. The study showed that this protein is capable of triggering an antitumor immune response. Furthermore, the study also showed that cells killed through hyperthermia release HSP70.

Finally, Jordan et al. ${ }^{(8)}$, using the brain tumor animal model (RG-2), proved the efficacy of MNP with two different types of coating: carboxy-dextran and aminosilane. As compared to controls, tumor dimension or histology did not vary after MHT. Cell proliferation decreased in the group treated with aminosilane-coated particles. In this same group, the average survival time of the animals increased. The gain in survival time was associated with the increase of intratumor temperature observed during treatment. Aminosilane-coated particles remained stable within the tumor when compared to carboxy-dextran coated particles. Furthermore, histological analysis showed that aminosilane-coated particles presented good distribution in the tumor tissue. The authors of the study concluded that thermotherapy using aminosilanecoated MNP was efficient and prolonged survival time of animals used in the tumor model.

Table 1 summarizes the main findings observed in studies that used animal models to evaluate the MHT in treatment of gliomas.

\section{In vivo and ex vivo experiments in humans}

Jordan et al. ${ }^{(19)}$ were the first to study the use of MHT in humans. These authors presented a new system for the use of magnetic field to generate hyperthermia through magnetic fluids for future applications in the treatment of glioblastomas and 
prostate carcinoma. Yet, Maier-Hauff et al. ${ }^{(17)}$ were the first to use this technique in 14 patients, in order to study the efficacy and tolerability of hyperthermia induced by aminosilane-coated MNP associated with radiation therapy in recurrent glioblastoma multiforme. The following inclusion criteria were used in the study: age equal to or greater than 18 years; life expectancy longer than 3 months; tumor diameter less than $5 \mathrm{~cm}$; absence of multilocular growth; no metal object near the tumor focus. Each patient underwent an average of six thermotherapy sessions. Prior to the sessions, patients received, in average, $0.2 \mathrm{ml}$ magnetic fluid per $\mathrm{ml}$ of tumor volume. Intratumor temperature during the sessions reached, in average, $44.6^{\circ} \mathrm{C}$. After each session of thermotherapy, patients were submitted to simple fraction (2 Gy) of an average of 30 Gy radiotherapy series. All patients tolerated MNP instillation with no complications or adverse effects. Few adverse effects were observed with AMF, except for a few patients that complained of a mild sensation of heat in the head. The authors of the study analyzed some aspects, such as survival and local tumor control. Nine patients died due to tumor progression; nonetheless, four deaths were not associated with tumor growth, nor with thermotherapy, but were caused by medical prescription. According to this study, MHT can be satisfactorily employed in the treatment of brain tumors, because it can be safely applied to patients with glioblastoma, with minimal or no local symptom. The use of MHT is currently undergoing validation in a phase II clinical trial involving 65 patients with recurrent glioblastoma.

Later, van Landeghem et al. ${ }^{(18)}$ presented the first ex vivo neuropathology study in three patients with glioblastoma who underwent MHT (Table 3). In this study, the inclusion criteria were 18 years of age or older, life expectancy longer than 3 months; tumor diameter less than $5 \mathrm{~cm}$; absence of multilocular growth, no metal object near the tumor focus. MHT treatment was used as a second line of treatment after tumor recurrence and was always associated with other therapies (see Table 3). The amount of magnetic liquid instilled into the tumor varied between 4.2 and $4.5 \mathrm{ml}$. With the use of AMF the tumor temperature among patients varied from 49.5 to $65.6^{\circ} \mathrm{C}$. After MHT, survival ranged from 2.1 to 7.9 months (for more details, see table 3 ). Among other findings listed in table 3 , the pathological results described the presence of numerous nanoparticles at tumor site, macrophages in the main extension and, subsequently, a necrotic area inherent to the tumor. Histology analyses revealed that nanoparticles were dispersed or identified as aggregates, and necrotic areas were limited to the site of nanoparticle instillation, indicating they should be instilled in multiple sites. Immunohistochemical data showed that nanoparticles were primarily internalized by macrophages, whereas internalization by tumor cells was minimal. Based on these results, the authors suggested that macrophage internalization would be promoted by the application of MHT and that this would lead to necrosis and subsequent phagocyte infiltration and activation.

\section{CONCLUSION}

This review discussed the use of MHT technique to treat gliomas. Murine experimental models demonstrated MHT efficacy, with increased survival in animals used for tumor induction; in some cases, shrinkage or total regression of the tumor mass was observed. On the other hand, clinical studies showed that the MHT is promising as a complementary therapy associated with other classic treatments, and may contribute to make brain tumor management more effective. Thus, it was concluded that MHT is effective in destroying brain tumor cells, and the development and improvement of nanocomposites and equipment that generate magnetic fields will contribute to refining the MHT technique, thus establishing it as an auxiliary tool in the treatment of gliomas in humans.

\section{ACKNOWLEDGEMENTS}

This work was financed by Instituto Israelita de Ensino e Pesquisa Albert Einstein - IIEPAE, CAPES, CNPq and FINEP.

\section{REFERENCES}

1. Central Brain Tumor Registry of the United States. CBTRUS statistical report. Primary brain and central nervous system. Tumors diagnosed in the United States in 2004-2006 [Internet]. 2010 [cited 2010 May 20]. Avaliable from: http://www. cbtrus.org/2010-NPCR-SEER/CBTRUS-WEBREPORT-Final-3-2-10.pdf

2. American Brain Tumor Association. Gliomas [Internet]. 2010 [cited 2010 May 20]. Available from: http://www.abta.org/index.cfm?contentid=230\&GliomaGlioblastoma-oligodendroglioma.

3. Parney IF, Hao C, Petruk KC. Glioma immunology and immunotherapy. Neurosurgery. 2000;46(4):778-91.

4. Brandes AA, Tosoni A, Franceschi E, Reni M, Gatta G, Vecht C. Glioblastoma in adults. Crit Rev Oncol Hematol. 2008;67(2):139-52.

5. Wen PY, Kesari S. Malignant gliomas in adults. N Engl J Med. 2008;359(5):492-507.

6. Cavaliere R, Ciocatto EC, Giovanella BC, Heidelberger C, Johnson RO, Margottini M, et al. Selective heat sensitivity of cancer cells. Biochemical and clinical studies. Cancer. 1967;20(9): 1351-81.

7. Brusentsov NA, Nikitin LV, Brusentsova TN, Kuznetsov AA, Bayburtskiy FS, Shumakov LI, et al. Magnetic fluid hyperthermia of the mouse experimental tumor. J Magn Magn Mater. 2002;252(1-3):378-80. 
8. Jordan A, Scholz R, Maier-Hauff K, van Landeghem FK, Waldoefner N, Teichgraeber $U$, et al. The effect of thermotherapy using magnetic nanoparticles on rat malignant glioma. J Neurooncol. 2006;78(1):7-14.

9. Ito A, Shinkai M, Honda H, Yoshikawa K, Saga S, Wakabayashi T, et al. Heat shock protein 70 expression induces antitumor immunity during intracellular hyperthermia using magnetite nanoparticles. Cancer Immunol Immunother. 2003;52(2):80-8.

10. Yanase M, Shinkai M, Honda H, Wakabayashi T, Yoshida J, Kobayashi T. Intracellular hyperthermia for cancer using magnetite cationic liposomes: ex vivo study. Jpn J Cancer Res. 1997;88(7):630-2.

11. Yanase M, Shinkai M, Honda H, Wakabayashi T, Yoshida J, Kobayashi T. Intracellular hyperthermia for cancer using magnetite cationic liposomes: an in vivo study. Jpn J Cancer Res. 1998;89(4):463-9.

12. Yanase M, Shinkai M, Honda $H$, Wakabayashi T, Yoshida J, Kobayashi T. Antitumor immunity induction by intracellular hyperthermia using magnetite. Jpn J Cancer Res. 1998;89(7):775-82.

13. Shinkai M, Yanase M, Suzuki M, Honda H, Wakabayashi T, Yoshida J, et al. Intracellular hyperthermia for cancer using magnetite cationic liposomes. J Magn Magn Mater. 1999;194(1-3):176-84.
14. Le B, Shinkai M, Kitade T, Honda H, Yoshida J, Wakabayashi T, et al. Preparation of tumor-specific magnetoliposomes and their application for hyperthermia. J Chem Eng Japan. 2001;34(1):66-72.

15. Ito A, Shinkai M, Honda H, Kobayashi T. Heat-inducible TNF-alpha gene therapy combined with hyperthermia using magnetic nanoparticles as a novel tumortargeted therapy. Cancer Gene Ther. 2001;8(9):649-54.

16. Ohno T, Wakabayashi T, Takemura A, Yoshida J, Ito A, Shinkai M, et al. Effective solitary hyperthermia treatment of malignant glioma using stick type CMC-magnetite. In vivo study. J Neurooncol. 2002;56(3):233-9.

17. Maier-Hauff K, Rothe R, Scholz R, Gneveckow U, Wust P, Thiesen B, et al. Intracranial thermotherapy using magnetic nanoparticles combined with external beam radiotherapy: results of a feasibility study on patients with glioblastoma multiforme. J Neurooncol. 2007;81(1):53-60.

18. van Landeghem FK, Maier-Hauff K, Jordan A, Hoffmann KT, Gneveckow U, Scholz $R$, et al. Post-mortem studies in glioblastoma patients treated with thermotherapy using magnetic nanoparticles. Biomaterials. 2009;30(1):52-7.

19. Jordan A, Scholz R, Maier-Hauff K, Johannsen M, Wust P, Nadobny J, et al. Presentation of a new magnetic field therapy system for the treatment of human solid tumors with magnetic fluid hyperthermia. J Magn Magn Mater. 2001;225(1-2):118-26. 